DIW BERLIN

Discussion

Papers
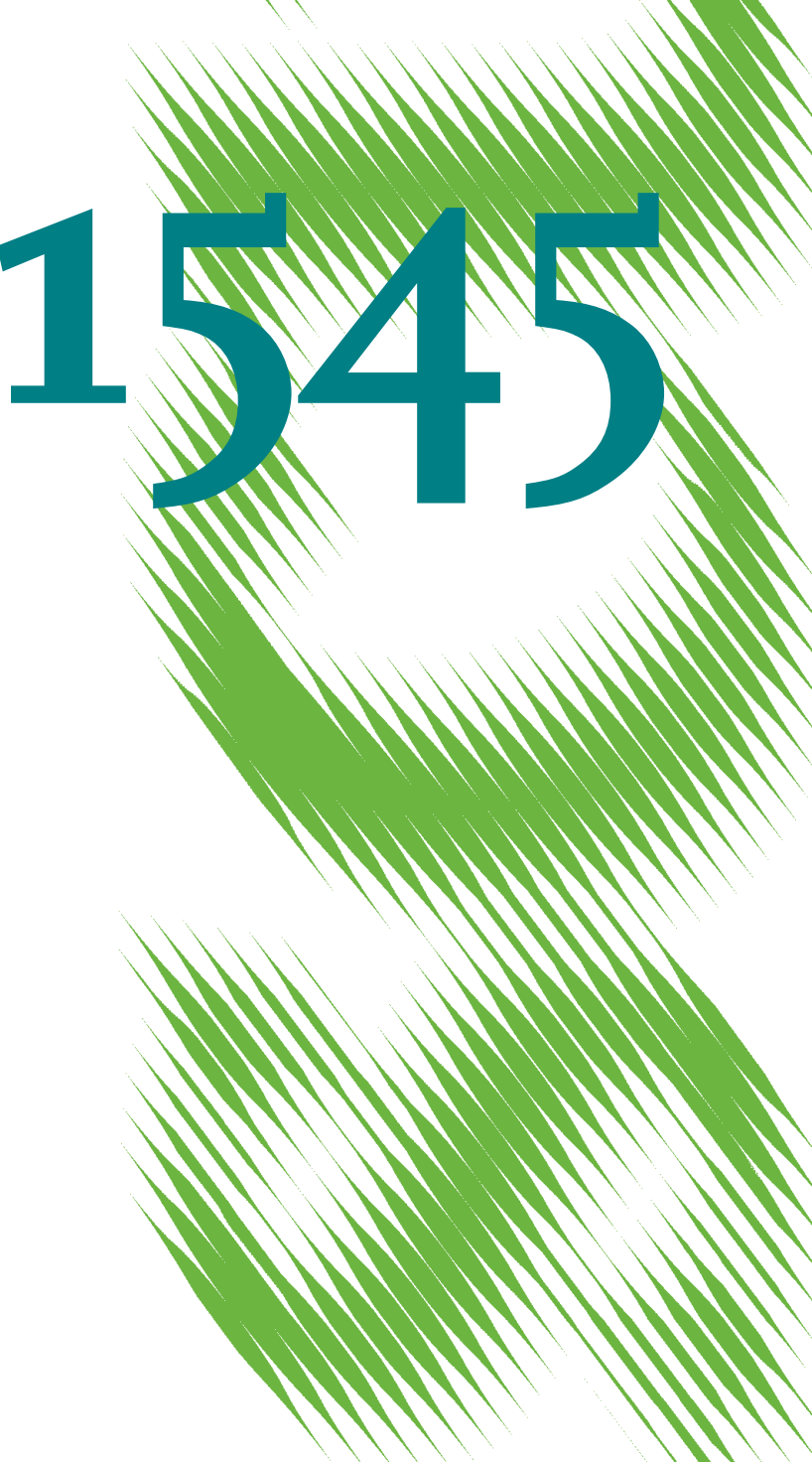

MIIIIMIMIMIII

Macro News and Exchange Rates in the BRICS 
Opinions expressed in this paper are those of the author(s) and do not necessarily reflect views of the institute.

IMPRESSUM

(C) DIW Berlin, 2016

DIW Berlin

German Institute for Economic Research

Mohrenstr. 58

10117 Berlin

Tel. +49 (30) $89789-0$

Fax +49 (30) $89789-200$

http://www.diw.de

ISSN electronic edition 1619-4535

Papers can be downloaded free of charge from the DIW Berlin website:

http://www.diw.de/discussionpapers

Discussion Papers of DIW Berlin are indexed in RePEc and SSRN:

http://ideas.repec.org/s/diw/diwwpp.html

http://www.ssrn.com/link/DIW-Berlin-German-Inst-Econ-Res.html 


\title{
Macro News and Exchange Rates in the BRICS
}

\author{
Guglielmo Maria Caporale, Fabio Spagnolo and Nicola Spagnolo \\ Department of Economics and Finance, Brunel University London, UK
}

February 2, 2016

\begin{abstract}
This paper examines the effects of newspaper headlines on the exchange rates visa-vis both the US dollar and the euro for the currencies of the BRICS (Brazil, Russia, India, China and South Africa). The data are daily and cover the period 03/1/2000$12 / 5 / 2013$. The estimated VAR-GARCH $(1,1)$ model allows for both mean and volatility spillovers and for the possible impact of the recent financial crisis as well. The results differ across countries, but provide in a number of cases evidence of significant spillovers, whose strength appears to have increased during the crisis. Further, given the increasingly global role of these countries, their FX markets have become more responsive to foreign news.
\end{abstract}

Keywords: BRICS, Exchange Rates, GARCH model, Macro news.

JEL Classification: C32, F36, G15.

\footnotetext{
${ }^{*}$ Corresponding author: Professor Guglielmo Maria Caporale, Research Professor at DIW Berlin. Department of Economics and Finance, Brunel University London, UB8 3PH, UK. Tel.: +44 (0)1895 266713. Fax: +44 (0)1895 269770. E-mail: Guglielmo-Maria.Caporale@brunel.ac.uk
} 


\section{Introduction}

The effects of macroeconomic news on exchange rates have been analysed in numerous recent studies: since FX markets are always open, the immediate impact of news can be more easily investigated than in the case of other financial markets. Either daily (Galati and Ho, 2001, etc.) or high-frequency data have been used (Andersen et al., 2007, etc.), and the results rationalised on the basis of different models of exchange rate determination, such as the monetary or the portfolio balance model (e.g., Balduzzi et al., 2001). Most of the available evidence concerns the developed economies, and typically considers only mean spillovers; one of the few exceptions is the study by Egert and Kocenda (2014), who focused on the CEECs and estimated GARCH models. Interestingly, some papers have considered investor psychology and linked media pessimism to low investor sentiment (Tetlock, 2007). Further, as highlighted by Birz and Lott (2011), the effects of news (surprises) could depend on their interpretation by the press, as reflected by newspaper headlines read by agents.

This paper examines the linkages between macro news and exchange rates in the BRICS (Brazil, Russia, India, China and South Africa), a particularly interesting set of countries to consider given their increasingly important role in the world economy as a result of their rapidly growing share in global trade in the last two decades. In 1990, the BRICS accounted for only $3 \%$ of global trade, but this share had doubled by the turn of the century, and by 2011 they accounted for $19 \%$ and 16\% respectively of global exports and imports of goods and services. A double-digit year-on-year growth in merchandise trade had made China the largest exporter and the second largest importer of merchandise goods by then. Russia and India have also entered the list of the world top 20 merchandise exporters and importers. The merchandise trade balance is in surplus in the case of China, Russia and Brazil whilst it is in deficit in the case of India and South Africa. In 2014 imports and exports between the eurozone and the BRICS reached a total value of $551 \mathrm{mln}$ and $340 \mathrm{mln}$ euros respectively (European Commission, Directorate General for Trade). These countries' export-oriented growth has led to an increase in trade with the US in recent years. In 2008, the two-way trade with the BRICS amounted to $16 \%$ of total US trade, up from $9 \%$ a decade earlier. The US merchandise deficit with the BRICS had widened to $\$ 290$ billion by 2008 , primarily owing to surging imports from China, the fastest growing economy among the US main trading partners.

The present study contributes to the relevant literature in various ways, more specifically: (i) it focuses on the BRICS, not previously examined in this context despite their growing importance highlighted above, (ii) it considers both mean and volatility spillovers by estimating a VAR-GARCH $(1,1)$ model, allowing for a possible impact of the recent financial crisis as well, (iii) it carries out the analysis for two sets of exchange rates, vis-a-vis the US dollar and the euro respectively, and (iv) it uses newspaper headlines as a proxy for agents' interpretation of news releases. The layout is as follows. Section 2 outlines the econometric modelling approach. Section 3 describes the data and presents the empirical findings. Section 4 summarises the main findings and offers some concluding remarks. 


\section{The model}

We represent the first and second moments of the BRICS exchange rate returns (vis-a-vis the US dollar and the euro respectively) and macro news (as reported by newspapers in the form of headlines) using a VAR-GARCH $(1,1)$ process. In its most general specification the model takes the following form:

$$
\mathbf{x}_{t}=\boldsymbol{\alpha}+\boldsymbol{\beta} \mathbf{x}_{t-1}+\mathbf{u}_{t}
$$

where $\mathbf{x}_{t}=\left(\right.$ ExRate Re $t_{t}$, DomesticNews, US (eurozone) News $\left.s_{t}\right)$ and $\mathbf{x}_{t-1}$ is the corresponding vector of lagged variables. The residual vector $\mathbf{u}_{t}=\left(u_{1, t}, u_{2, t}, u_{3, t}\right)$ is trivariate and normally distributed $\mathbf{u}_{t} \mid I_{t-1} \sim\left(\mathbf{0}, H_{t}\right)$, its conditional variance covariance matrix being given by:

$$
H_{t}=\left[\begin{array}{lll}
h_{11 t} & h_{12 t} & h_{13 t} \\
h_{12 t} & h_{22 t} & h_{23 t} \\
h_{13 t} & h_{23 t} & h_{33 t}
\end{array}\right]
$$

The parameter vector of the mean return equation (1) includes the constant $\boldsymbol{\alpha}=\left(\alpha_{1}, \alpha_{2}, \alpha_{3}\right)$, and the autoregressive term, $\boldsymbol{\beta}=\left(\beta_{11}, \beta_{12}+\beta_{12}^{*}, \beta_{13}+\beta_{13}^{*}\left|0, \beta_{22}, 0\right| 0,0, \beta_{33}\right)$, which measures the effect on mean exchange rate returns of domestic $\left(\beta_{12}\right)$ and euro/US dollar $\left(\beta_{13}\right)$ negative news as a percentage of total news. The parameter matrices for the variance Equation (2) are $C_{0}$ (which is restricted to be upper triangular), and $A_{11}$ and $G_{11}$ (with zero restrictions such that only unidirectional volatility spillovers from macro news volatility to exchange rate volatility are allowed). In order to account for the possible effects of the recent financial crisis, we include a dummy variable (denoted by ${ }^{*}$ ) with a switch on 15 September 2008, i.e. on the day of the collapse of Lehman Brothers. Therefore, the second moment takes the following form ${ }^{1}$ :

$$
H_{t}=C_{0}^{\prime} C_{0}+A_{11}^{\prime}\left[\begin{array}{lll}
e_{1, t-1}^{2} & e_{2, t-1} e_{1, t-1} & e_{3, t-1} e_{1, t-1} \\
e_{1, t-1} e_{2, t-1} & e_{2, t-1}^{2} & e_{3, t-1} e_{2, t-1} \\
e_{1, t-1} e_{3, t-1} & e_{2, t-1} e_{3, t-1} & e_{3, t-1}^{2}
\end{array}\right] A_{11}+G_{11}^{\prime} H_{t-1} G_{11}
$$

where

$$
A_{11}=\left[\begin{array}{lll}
a_{11} & 0 & 0 \\
a_{21}+a_{21}^{*} & a_{22} & 0 \\
a_{31}+a_{31}^{*} & 0 & a_{33}
\end{array}\right] ; G_{11}=\left[\begin{array}{lll}
g_{11} & 0 & 0 \\
g_{21}+g_{21}^{*} & g_{22} & 0 \\
g_{31}+g_{31}^{*} & & g_{33}
\end{array}\right]
$$

The standard errors are calculated using the quasi-maximum likelihood methods of Bollerslev and Wooldridge (1992), which is robust to the distribution of the underlying residuals.

\footnotetext{
${ }^{1}$ The parameters $\left(a_{21}\right)$ and $\left(a_{31}\right)$ in Equation (3) measure the causality effect of domestic and US (eurozone) macro news volatility respectively, the possible effect of the 2008 financial crisis being captured by $\left(a_{21}+a_{21}^{*}\right)$ and $\left(a_{31}+a_{31}^{*}\right)$ instead.
} 


\section{Empirical Analysis}

We use daily data (from Bloomberg) on the exchange rates vis-a-vis the US dollar and the euro of the currencies of the BRICS (Brazil, Russia, India, China and South Africa) over the period $03 / 1 / 2000-12 / 5 / 2013$, for a total of 3058 observations, daily returns being defined as the logarithmic differences of exchange rates.

We consider news coverage of four macroeconomic series, i.e. GDP, unemployment, retail sales and durable goods (as in Birz and Lott, 2013). The data for the News Index are collected from Bloomberg where news coverage is proxied by story headlines counts. News headlines were selected using an extensive search string, containing words indicating articles dealing with macro variables, and also allowing to distinguish between articles with a positive or negative connotation towards GDP, unemployment, retail sales and durable goods. News headlines about unemployment and GDP are the most frequent, whereas there is less coverage of retail sales and durable goods releases. The index we use does not distinguish between different types of macro news, since our focus is on the effects of domestic and US (or eurozone) macro news, respectively, as reported by the media. The daily negative news percentage is defined as negative news/(negative news + positive news).

\section{Please Insert Table 1 about here}

In order to test the adequacy of the models, Ljung-Box portmanteau tests were performed on the standardized and squared standardized residuals. Overall, the results indicate that the VAR-GARCH $(1,1)$ specification is data congruent and captures satisfactorily the persistence in exchange rate changes and their volatility. The estimated mean of daily exchange rate changes is negative for the Russia, India and South Africa against the US dollar (a US dollar appreciation), negative for India and China against the euro (a euro appreciation), and positive (a US dollar and euro depreciation) for the other currencies. Exchange rate changes are found to exhibit high persistence with the exception of the Chinese exchange rate vis-a-vis the US dollar $\left(g_{11}=0.83\right)$. The estimated VAR-GARCH $(1,1)$ model with the associated robust p-values and likelihood function values are presented in Table 1. We select the optimal lag length of the mean equation using the Schwarz information criterion. The results suggest that there are limited dynamic linkages between the first moments compared to the second moments. In particular, as far as the effects of domestic news on exchange rate returns $\left(\beta_{12}\right)$ are concerned, we find positive and significant causality at the standard $5 \%$ significance level in the cases of the Brazilian and Chinese exchange rates vis-a-vis the US dollar and the Russian one vis-a-vis the euro $\left(\beta_{12}=0.097\right)$. The financial crisis appears to have had an impact on the spillovers from domestic news only in the case of the exchange rate of the Indian rupee vis-a-vis the euro $\left(\beta_{12}^{*}=0.367\right)$. As for the effects of foreign news, there is evidence of negative and significant causality in the cases of the Brazilian exchange rate vis-a-vis the US dollar $\left(\beta_{13}=-0.232\right)$ and the Russian one vis-a-vis the euro $\left(\beta_{13}-0.188\right)$. During the crisis period this spillover effect has become stronger in the case of the Brazilian exchange rates and appeared also in the cases of the Indian and South African exchange rates vis-a-vis the euro and the Chinese one vis-a-vis the US dollar $\left(\beta_{13}=-0.135\right)$.

Causality effects ${ }^{2}$ in the conditional variance vary in magnitude across countries (note

\footnotetext{
${ }^{2}$ Please note that the term causality refers to Granger causality and therefore a structural interpretation
} 
that the signs on cross-market volatilities cannot be determined). It appears that domestic news volatility has an impact on exchange rate volatility in the Brazilian, Russian, Indian and Chinese case; volatility spillovers are also found from eurozone news in the cases of Brazil, India and South Africa, and from US news in the case of China $\left(a_{31}=-0.001\right)$. Furthermore, there is evidence that the 2008 crisis affected the causality-in-variance dynamics. In particular, during the crisis domestic news volatility have started having effects in the case of the Russian $\left(a_{31}^{*}=-0.369\right)$ as well as the Indian exchange rate $\left(a_{31}=0.208\right)$ vis-a-vis the US dollar. Stronger news volatility effects are found in the cases of the Brazilian, Indian and South African exchange rates vis-a-vis the euro.

\section{Conclusions}

This paper has examined the effects of newspaper headlines on the exchange rates vis-a-vis both the US dollar and the euro for the currencies of the BRICS using daily data over the period 03/1/2000-12/5/2013. The increasingly important role of these countries in the world economy as a result of their rapidly growing share in global trade and the lack of previous empirical evidence concerning them specifically motivates our focus. The estimated VAR$\operatorname{GARCH}(1,1)$ model allows for both mean and volatility spillovers as well as for the possible impact of the recent financial crisis. The analysis is very comprehensive, since it considers two sets of the exchange rates, the US and the eurozone both being among the main trade partners of the BRICS. The results differ across countries, but provide in a number of cases evidence of significant spillovers, whose strength appears to have increased during the crisis. On the whole, the empirical evidence presented here can be seen as confirming the important role of news as interpreted by the press (and therefore of investor psychology), not only in the case of the developed economies, but also in the case of the BRICS: their increasingly global role appears to have made their FX markets more responsive to foreign news in addition to domestic news as one would have expected.

\section{References}

[1] Andersen, T.G., Bollerslev, T., Diebold, F.X. and C. Vega (2007), "Real-time price discovery in global stock, bond and foreign exchange markets", Journal of International Economics, 73, 2, 251-277.

[2] Balduzzi, P., Elton, E.J. and T.C. Green (2001), "Economic news and the yield curve: evidence from the US Treasury market", Journal of Financial and Quantitative Analysis, $36,4,523-543$.

[3] Birz, G. and J.R. Lott (2011), "The effect of macroeconomic news on stock returns: new evidence from newspaper coverage", Journal of Banking and Finance, 35, 2791-2800.

[4] Directorate General for Trade, European Commission, 2014

[5] Egert, B. and E. Kocenda (2014), "The impact of macro news and central bank communication on emerging European forex markets", Economic Systems, 38, 1, 73-88.

is not appropriate. 
[6] Engle, R.F., and K.F. Kroner (1995), "Multivariate simultaneous generalized ARCH", Econometric Theory, 11, 122-150.

[7] Galati, G. and C. Ho (2001), "Macroeconomic news and the euro/dollar exchange rate", BIS WP no. 105, Bank for International Settlements, Basel, Switzerland.

[8] Ljung, G.M. and G.E.P. Box (1978), "On a measure of lack of fit in time series models", Biometrika 65, 297-303.

[9] Tetlock, P.C. (2007), "Giving content to investor sentiment: the role of media in the stock market", Journal of Finance, 62, 3, 1139-1168. 
TABLE 1: Estimated VAR-GARCH(1,1) model. Ex rate vis-a-vis the US dollar and the euro

\begin{tabular}{|c|c|c|c|c|c|c|c|c|c|c|}
\hline & \multicolumn{2}{|c|}{ Brazil } & \multicolumn{2}{|c|}{ Russia } & \multicolumn{2}{|c|}{ India } & \multicolumn{2}{|c|}{ China } & \multicolumn{2}{|c|}{ S. Africa } \\
\hline & Dollar & Euro & Dollar & Euro & Dollar & Euro & Dollar & Euro & Dollar & Euro \\
\hline & \multicolumn{10}{|c|}{ Conditional Mean Equation } \\
\hline$\alpha_{1}$ & $\begin{array}{l}0.151 \\
(0.005)\end{array}$ & $\begin{array}{l}0.041 \\
(0.583)\end{array}$ & $\begin{array}{c}-0.001 \\
(0.933)\end{array}$ & $\begin{array}{l}0.058 \\
(0.037)\end{array}$ & $\begin{array}{c}-0.018 \\
(0.239)\end{array}$ & $\begin{array}{l}0.061 \\
(0.164)\end{array}$ & $\begin{array}{l}0.018 \\
(0.000)\end{array}$ & $\begin{array}{c}-0.003 \\
(0.898)\end{array}$ & $\begin{array}{c}-0.054 \\
(0.527)\end{array}$ & $\begin{array}{c}-0.074 \\
(0.369)\end{array}$ \\
\hline$\alpha_{2}$ & $\begin{array}{c}0.471 \\
(0.000)\end{array}$ & $\begin{array}{c}0.472 \\
(0.000)\end{array}$ & $\begin{array}{l}0.472 \\
(0.000)\end{array}$ & $\begin{array}{l}0.473 \\
(0.000)\end{array}$ & $\begin{array}{l}0.464 \\
(0.000)\end{array}$ & $\begin{array}{l}0.456 \\
(0.000)\end{array}$ & $\begin{array}{l}0.431 \\
(0.000)\end{array}$ & $\begin{array}{l}0.441 \\
(0.000)\end{array}$ & $\begin{array}{l}0.468 \\
(0.000)\end{array}$ & $\begin{array}{l}0.473 \\
(0.000)\end{array}$ \\
\hline$\alpha_{3}$ & $\begin{array}{l}0.457 \\
(0.000)\end{array}$ & $\begin{array}{l}0.451 \\
(0.000)\end{array}$ & $\begin{array}{l}0.446 \\
(0.000)\end{array}$ & $\begin{array}{l}0.449 \\
(0.000)\end{array}$ & $\begin{array}{l}0.459 \\
(0.000)\end{array}$ & $\begin{array}{l}0.453 \\
(0.000)\end{array}$ & $\begin{array}{l}0.451 \\
(0.000)\end{array}$ & $\begin{array}{l}0.462 \\
(0.000)\end{array}$ & $\begin{array}{l}0.443 \\
(0.000)\end{array}$ & $\begin{array}{l}0.447 \\
(0.000)\end{array}$ \\
\hline$\beta_{11}$ & $\begin{array}{c}-0.051 \\
(0.000)\end{array}$ & $\begin{array}{c}-0.061 \\
(0.000)\end{array}$ & $\begin{array}{l}0.083 \\
(0.000)\end{array}$ & $\begin{array}{l}0.001 \\
(0.949)\end{array}$ & $\begin{array}{l}0.035 \\
(0.044)\end{array}$ & $\begin{array}{c}-0.013 \\
(0.495)\end{array}$ & $\begin{array}{c}-0.153 \\
(0.000)\end{array}$ & $\begin{array}{c}-0.024 \\
(0.199)\end{array}$ & $\begin{array}{c}-0.005 \\
(0.761)\end{array}$ & $\begin{array}{l}0.010 \\
(0.649)\end{array}$ \\
\hline$\beta_{12}$ & $\begin{array}{l}0.153 \\
(0.013)\end{array}$ & & & $\begin{array}{l}0.097 \\
(0.041)\end{array}$ & & & $\begin{array}{l}0.008 \\
(0.102)\end{array}$ & & & \\
\hline$\beta_{12}^{*}$ & & & & & & $\begin{array}{l}0.367 \\
(0.001)\end{array}$ & & & & \\
\hline$\beta_{13}$ & $\begin{array}{c}-0.232 \\
(0.009)\end{array}$ & & & $\begin{array}{c}-0.188 \\
(0.000)\end{array}$ & & & & & & \\
\hline$\beta_{13}^{*}$ & $\begin{array}{c}-0.211 \\
(0.050)\end{array}$ & & & & & $\begin{array}{c}-0.398 \\
(0.001)\end{array}$ & $\begin{array}{c}-0.135 \\
(0.001)\end{array}$ & & & $\begin{array}{c}-0.215 \\
(0.021)\end{array}$ \\
\hline \multicolumn{11}{|c|}{ Conditional Variance Equation } \\
\hline$c_{11}$ & $\begin{array}{l}0.131 \\
(0.000)\end{array}$ & $\begin{array}{l}0.225 \\
(0.000)\end{array}$ & $\begin{array}{l}0.024 \\
(0.000)\end{array}$ & $\begin{array}{l}0.041 \\
(0.000)\end{array}$ & $\begin{array}{l}0.029 \\
(0.000)\end{array}$ & $\begin{array}{l}0.083 \\
(0.000)\end{array}$ & $\begin{array}{l}0.000 \\
(0.000)\end{array}$ & $\begin{array}{l}0.028 \\
(0.001)\end{array}$ & $\begin{array}{l}0.156 \\
(0.000)\end{array}$ & $\begin{array}{l}0.141 \\
(0.000)\end{array}$ \\
\hline$c_{22}$ & $\begin{array}{l}0.006 \\
(0.034)\end{array}$ & $\begin{array}{l}0.011 \\
(0.007)\end{array}$ & $\begin{array}{l}0.009 \\
(0.000)\end{array}$ & $\begin{array}{l}0.009 \\
(0.000)\end{array}$ & $\begin{array}{l}0.009 \\
(0.000)\end{array}$ & $\begin{array}{l}0.007 \\
(0.000)\end{array}$ & $\begin{array}{l}0.002 \\
(0.000)\end{array}$ & $\begin{array}{l}0.005 \\
(0.000)\end{array}$ & $\begin{array}{c}-0.001 \\
(0.000)\end{array}$ & $\begin{array}{c}-0.001 \\
(0.000)\end{array}$ \\
\hline$c_{33}$ & $\begin{array}{l}0.008 \\
(0.001)\end{array}$ & $\begin{array}{l}0.003 \\
(0.001)\end{array}$ & $\begin{array}{l}0.002 \\
(0.000)\end{array}$ & $\begin{array}{l}0.004 \\
(0.000)\end{array}$ & $\begin{array}{l}0.001 \\
(0.000)\end{array}$ & $\begin{array}{l}0.004 \\
(0.000)\end{array}$ & $\begin{array}{l}0.006 \\
(0.000)\end{array}$ & $\begin{array}{c}-0.005 \\
(0.000)\end{array}$ & $\begin{array}{l}0.006 \\
(0.002)\end{array}$ & $\begin{array}{l}0.007 \\
(0.003)\end{array}$ \\
\hline$g_{11}$ & $\begin{array}{l}0.929 \\
(0.000)\end{array}$ & $\begin{array}{l}0.901 \\
(0.000)\end{array}$ & $\begin{array}{c}-0.951 \\
(0.000)\end{array}$ & $\begin{array}{l}0.957 \\
(0.000)\end{array}$ & $\begin{array}{c}-0.943 \\
(0.000)\end{array}$ & $\begin{array}{c}-0.968 \\
(0.000)\end{array}$ & $\begin{array}{l}0.831 \\
(0.000)\end{array}$ & $\begin{array}{l}0.985 \\
(0.000)\end{array}$ & $\begin{array}{l}0.951 \\
(0.000)\end{array}$ & $\begin{array}{c}-0.954 \\
(0.000)\end{array}$ \\
\hline$g_{21}$ & & & & & & & $\begin{array}{l}0.004 \\
(0.000)\end{array}$ & & & \\
\hline \multicolumn{11}{|l|}{$g_{21}^{*}$} \\
\hline$g_{22}$ & $\begin{array}{l}0.986 \\
(0.000)\end{array}$ & $\begin{array}{l}0.985 \\
(0.000)\end{array}$ & $\begin{array}{l}0.990 \\
(0.000)\end{array}$ & $\begin{array}{l}0.990 \\
(0.000)\end{array}$ & $\begin{array}{l}0.987 \\
(0.000)\end{array}$ & $\begin{array}{l}0.985 \\
(0.000)\end{array}$ & $\begin{array}{l}0.991 \\
(0.000)\end{array}$ & $\begin{array}{l}0.989 \\
(0.000)\end{array}$ & $\begin{array}{l}0.994 \\
(0.000)\end{array}$ & $\begin{array}{c}-0.994 \\
(0.000)\end{array}$ \\
\hline$g_{31}$ & & & $\begin{array}{c}-0.088 \\
(0.047)\end{array}$ & & & & $\begin{array}{l}0.001 \\
(0.029)\end{array}$ & & & \\
\hline$g_{31}^{*}$ & & & & & & & & & & $\begin{array}{l}0.911 \\
(0.013)\end{array}$ \\
\hline$g_{33}$ & $\begin{array}{l}0.995 \\
(0.000)\end{array}$ & $\begin{array}{l}0.991 \\
(0.000)\end{array}$ & $\begin{array}{l}0.995 \\
(0.000)\end{array}$ & $\begin{array}{l}0.992 \\
(0.000)\end{array}$ & $\begin{array}{l}0.995 \\
(0.000)\end{array}$ & $\begin{array}{l}0.991 \\
(0.000)\end{array}$ & $\begin{array}{l}0.995 \\
(0.000)\end{array}$ & $\begin{array}{l}0.992 \\
(0.000)\end{array}$ & $\begin{array}{l}0.995 \\
(0.000)\end{array}$ & $\begin{array}{l}0.991 \\
(0.000)\end{array}$ \\
\hline$a_{11}$ & $\begin{array}{l}0.346 \\
(0.000)\end{array}$ & $\begin{array}{l}0.348 \\
(0.000)\end{array}$ & $\begin{array}{l}0.306 \\
(0.000)\end{array}$ & $\begin{array}{l}0.285 \\
(0.000)\end{array}$ & $\begin{array}{l}0.341 \\
(0.000)\end{array}$ & $\begin{array}{l}0.206 \\
(0.000)\end{array}$ & $\begin{array}{l}0.333 \\
(0.000)\end{array}$ & $\begin{array}{l}0.161 \\
(0.000)\end{array}$ & $\begin{array}{l}0.274 \\
(0.000)\end{array}$ & $\begin{array}{l}0.259 \\
(0.000)\end{array}$ \\
\hline$a_{21}$ & & $\begin{array}{l}0.313 \\
(0.037)\end{array}$ & $\begin{array}{l}0.051 \\
(0.038)\end{array}$ & $\begin{array}{c}-0.101 \\
(0.044)\end{array}$ & & $\begin{array}{l}0.143 \\
(0.009)\end{array}$ & $\begin{array}{l}0.001 \\
(0.007)\end{array}$ & & & \\
\hline$a_{21}^{*}$ & & & $\begin{array}{c}-0.369 \\
(0.000)\end{array}$ & & & & & & & \\
\hline$a_{22}$ & $\begin{array}{l}0.154 \\
(0.000)\end{array}$ & $\begin{array}{l}0.155 \\
(0.000)\end{array}$ & $\begin{array}{l}0.127 \\
(0.000)\end{array}$ & $\begin{array}{l}0.126 \\
(0.000)\end{array}$ & $\begin{array}{l}0.151 \\
(0.000)\end{array}$ & $\begin{array}{l}0.161 \\
(0.000)\end{array}$ & $\begin{array}{c}-0.121 \\
(0.000)\end{array}$ & $\begin{array}{l}0.134 \\
(0.000)\end{array}$ & $\begin{array}{l}0.097 \\
(0.000)\end{array}$ & $\begin{array}{l}0.099 \\
(0.000)\end{array}$ \\
\hline$a_{31}$ & & $\begin{array}{c}-0.375 \\
(0.008)\end{array}$ & & & & $\begin{array}{l}0.125 \\
(0.001)\end{array}$ & $\begin{array}{c}-0.001 \\
(0.000)\end{array}$ & & & $\begin{array}{l}0.234 \\
(0.044)\end{array}$ \\
\hline$a_{31}^{*}$ & & $\begin{array}{c}-0.401 \\
(0.046)\end{array}$ & & & $\begin{array}{l}0.208 \\
(0.001)\end{array}$ & $\begin{array}{l}0.349 \\
(0.001)\end{array}$ & & & & $\begin{array}{c}-0.245 \\
(0.041)\end{array}$ \\
\hline$a_{33}$ & $\begin{array}{l}0.099 \\
(0.000)\end{array}$ & $\begin{array}{l}0.132 \\
(0.000)\end{array}$ & $\begin{array}{l}0.101 \\
(0.050)\end{array}$ & $\begin{array}{l}0.124 \\
(0.000)\end{array}$ & $\begin{array}{l}0.099 \\
(0.000)\end{array}$ & $\begin{array}{l}0.129 \\
(0.000)\end{array}$ & $\begin{array}{l}0.099 \\
(0.000)\end{array}$ & $\begin{array}{l}0.126 \\
(0.000)\end{array}$ & $\begin{array}{l}0.100 \\
(0.000)\end{array}$ & $\begin{array}{l}0.199 \\
(0.000)\end{array}$ \\
\hline Lik. & 494.23 & 547.71 & 618.21 & 935.99 & 863.69 & 684.96 & 756.28 & 659.46 & 997.91 & 665.61 \\
\hline$L B$ & 4.34 & 8.04 & 6.05 & 6.44 & 8.56 & 5.16 & 5.98 & 4.67 & 6.88 & 7.51 \\
\hline$L B^{2}$ & 7.12 & 6.19 & 7.01 & 8.23 & 9.45 & 6.14 & 7.11 & 3.18 & 9.11 & 8.33 \\
\hline
\end{tabular}


Note: P-values are calculated using the quasi-maximum likelihood method of Bollerslev and Wooldridge (1992), which is robust to the distribution of the underlying residuals. Parameters not statistically significant at the $5 \%$ level are not reported. LB and $\mathrm{LB}^{2}$ are the Ljung-Box test (1978) of significance of autocorrelations of ten lags in the standardized and standardized squared residuals respectively. The parameters $\beta_{12}$ and $\beta_{13}$ measure the Granger causality effect of domestic and USA (Euro area) news on exchange rates respectively, .$a_{21}$ and $a_{31}$ measure the causality in variance effect. The effect of the 2008 financial crises on exchange rates is measured by $\left(\beta_{12}+\beta_{12}^{*}\right)$ and $\left(\beta_{13}+\beta_{13}^{*}\right)$ whereas $\left(a_{21}+a_{21}^{*}\right)$ and $\left(a_{31}+a_{31}^{*}\right)$ capture the effect on exchange rate return volatilities. The covariance stationarity condition is satisfied by all the estimated models, all the eigenvalues of $A_{11} \otimes A_{11}+G_{11} \otimes G_{11}$ being less than one in modulus. 